\title{
Analysis of the necessity and efficiency of the HEI diploma holder professional retraining needs in Adjara Autonomous Republic
}

\author{
George Abuselidze ${ }^{1, *}$ and Lia Davitadze ${ }^{1}$ \\ ${ }^{1}$ Batumi Shota Rustaveli State University, Ninoshvili, 35, 6010, Batumi, Georgia
}

\begin{abstract}
At the present stage, in the context of global economic and political problems, the educational space in countries with a small open economy is of particular importance, since it is recognized as one of the key elements of ensuring public welfare. In addition to the costs directly allocated to education in Georgia, the government finances various retraining courses, the need for which is due to the higher education programs which seem to be incompatible with the labour market. The purpose of this article is to determine the cost efficiency of retraining incurred by the state, and the reasons for these additional costs as well as the aspects of retraining (profession / qualification) provided to higher education diploma holders. This last group is of particular interest to us to determine what causes the need for services provided by the employment agency in the case of people with higher education which, possibly, leads us to gaps in study programs, which, in turn, can be caused by a) higher education programs, which cannot give graduates the proper skills; or/and b) the institution of higher education has not studied the required number of graduates/skills needed in the market (and determines the number of students according to its academic staff) and/or graduates with low academic performance (which are supported by the institution of higher education so as not to lose a voucher) need retraining.
\end{abstract}

\section{Introduction}

The development of the education system in countries with a small open economy should be focused on the implementation of national goals. The socio-economic situation in the country improves when the specialization of the workforce creates the opportunity to focus on areas where it is possible to work better through education. When the goals of the country's economic development are not provided with the development of educational potential, they cannot be achieved and economic prosperity is also delayed. This is proved by the example of more than 100 countries with different cultures and economic systems [10] and many more researches $[8,12]$ prove that Education increases welfare. Public policy should be aimed at expanding the principles of internationalization in learning and the growth of education as an

\footnotetext{
${ }^{*}$ Corresponding author: george.abuselidze@ bsu.edu.ge
} 
important area. All this makes it necessary to control public finances, as well as expand and increase its efficiency.

The aim of this article is to determine the cost efficiency of retraining incurred by the state, and the reasons for these additional costs. The subject of the study is the data on the costs of retraining for 2013-2018 provided by the employment agency AR, as well as the aspects of retraining (profession / qualification) provided to people who already have higher education. This last group is of particular interest to us to determine what causes the need for services provided by the employment agency in the case of people with higher education which, possibly, leads us to gaps in study programs, which, in turn, can be caused by a) higher education programs, which cannot give graduates the proper skills; or/and b) the institution of higher education has not studied the required number of graduates/skills needed in the market (and determines the number of students according to its academic staff) and/or graduates with low academic performance (which are supported by the institution of higher education so as not to lose a voucher) need retraining.

The following is assumed: professional retraining of the unemployed or long-term unemployed may be less effective $[9,14,15]$. Some studies show that a training program in the labor market can increase wages, but some studies do not show such effectiveness. Accordingly, the results of such programs and target groups may be different. In addition, we can assume that the employment agency is mainly used by those graduates who could not be employed and are looking for work.

\section{Research methods}

\subsection{Research instruments}

The policy definition and decision-making process in the development of professional retraining covers the collection, use and administration of resources, the main purpose of which should be to achieve the main goals of approved professional learning (trainings). According to Bodenhofer [6] and authors of paper [1, 2, 17-21], the assessment of the financing system combines two main aspects: a) financial resources are secured by current or future revenues and b) revenues are determined by the institutional form and / or individual support provided by the current market size.

The study "Strategic Development of Higher Education and Science in Georgia", prepared by the International Institute for Educational Policy Planning and Management, provides guidelines for a hypothetical model $[5,7]$ of increasing the compatibility of higher education with market requirements. According to the latter, a higher educational institution needs to monitor the number of graduates in relation to market requirements, collect, analyse and predict incompatibility; in addition, to monitor the compatibility of graduates' skills with market requirements and to reform the structure of the quality and qualification system in accordance with the mentioned requirements. In a hypothetical model, the specification of the roles and responsibilities of stakeholders is an important point in connection with the goal of balancing supply and demand (higher institutions, government, employers) and in particular, enhance the role of employers in developing and implementing training programs, quality assurance schemes and in the process of accreditation. One of the most important guidelines of the hypothetical model is also the promotion of youth employment and selfemployment indicators, which mean the involvement of higher education institutions in programs for providing information, monitoring and consulting, financial and infrastructural support (incubators and youth business networks).

In addition to the guidelines of the hypothetical model, the study provides a situation analysis in Georgia in this direction, according to which the information on the relationship 
between higher education and the labour market by 2013 was very poor, mainly due to the lack of a systematic approach to analysing the relationship between higher education and the labour market at the national level $[5,7]$. In addition, although the program accreditation standard mandated higher education institutions to develop programs in accordance with market requirements, performance indicators and sources of verification of the relevant points of the standard were vague; accordingly, sufficiently detailed tools of self-assessment and external evaluation did not provide a complete and objective assessment of the situation in this concept both at individual programs and at the level of all higher education. In the same study, a number of points are given as a conclusion, including point 3 , in which, as one of the hampering factors for the growth of feedback in higher education, the weak compatibility of the skills of graduates with the labour market is mentioned [7].

The study "The Impact of Higher Education on the Formation of the Labour Force" indicates the need to improve the quality control mechanisms for monitoring university education, which, according to the authors, are important to increase the compatibility of higher education with market requirements in Georgia. According to the study, more attention in higher education assessment schemes should be given to employment indicators, diverse and intensive forms of cooperation with the private and public sectors. In addition, when evaluating an academic program, it is important to pay more attention to the development of marketable skills.

\subsection{Research instruments}

Desk research - the strategy and education policy documents of Georgia was analysed; as well as the documents provided by the agency based on the Letter to the ministry of Health of Adjara Autonomous Republic.

Selection - The agency was selected as it is only state funded organization aimed at short term training courses to meet the market requirements and equip the trainees with the relevant skills.

\section{Results and discussion}

\subsection{Problem formulation}

In the document of the Government of Georgia "Strategy for the Socio-Economic Development of Georgia - Georgia 2020", the Government's economic policy considers improving the welfare of the population in addition to other activities, and plans to promote employment opportunities. The government strategy identifies several priorities for resolving the problems listed in the strategy and for ensuring economic growth, including the important problem of our study - the development of the labor market-oriented labor force. When reviewing the current situation of the development of the labor market-oriented workforce the strategy 2020 states that higher education systems both academic and vocational curriculums are less compatible with labor requirements $[13,16,17]$. The strategy calls promoting market development one of the directions of the policy to be implemented to develop labor market-oriented workforce policy which, among other things, means the institutionalization of labor market research and the creation / development of a database; ensuring effective relations between the employer and the applicant $[13,16,17]$, as well as continuous support of education.

According to the "Strategy of Education and Science for 2017-2021," a list of issues including the quality of education and services, the relationship of education with the labor market, the development of entrepreneurial skills at any stage of training, support for science 
and research remain problematic, despite thorough reforms. In accordance with the strategy, the education system should provide young people with the proper competence, knowledge and skills to meet new challenges that must be solved by the Ministry of Education and Science through appropriate legal and regulatory changes at all stages of education [16, 17]. In the SWAT analysis presented in the strategy, the weaknesses of the education system are the irrelevance of the education system with the requirements of the labor market, as well as insufficient coordination between research institutes and the public sector [13, 16, 17]. As part of the recommendation, the strategy states that in order for the graduate to be competitive in the local and international labor markets, updated and high-quality training programs are required. And that new standards and authorization procedures require the participation of international experts, students and employers in the assessment of universities, as well as aimed at improving the quality $[16,17]$. The first goal of this strategy, which concerns the further modernization of the education system, promoting internationalization and improving quality, directly indicates that, in parallel with social, personal and professional development, higher education should provide a person with a decent job opportunity. However, the reality is dramatically different, and training programs go beyond the demands of the labor market. The strategy considers it important to study graduate employment indicators, orient training programs on the labor market and strengthen centers for promoting employment of students and graduates at universities.

\subsection{Discussion}

According to the research, based on the data of 2017 of the $28 \mathrm{EU}$ countries the average employment data of the HEI diploma holders who graduated for the last three years makes up $82,8 \%$. The highest figure $-94,5 \%$ is in Malta and $90.9 \%$ in Germany, while the lowest data is in Greece $-52 \%$ and Italy $-55,2 \%$ and only $41 \%$ in Georgia [3].

Therefore, the main aim of the HE policy improvement should be to prepare students for the vocational education and proper application of the intellectual property [4]. In this regards, since 2013 the employment agency of Adjara Autonomous Republic has been implementing the following sub-programs: a) promotion of the employment b) employment promotion through vocational training / retraining. The aim of the sub-programs is to support various groups of people in employment promotion and to reduce misbalance of the demandsupply in the regional labor market.

The project included only professional retraining component between 2013 - 2017, under which the job seekers had opportunity to obtain or/and improve professional skills in the professions relevant to the labor with the help of short-term intensive module (4 month course).

The distribution of these beneficiaries under different sub-programs in different occupational directions by year is as follows: 


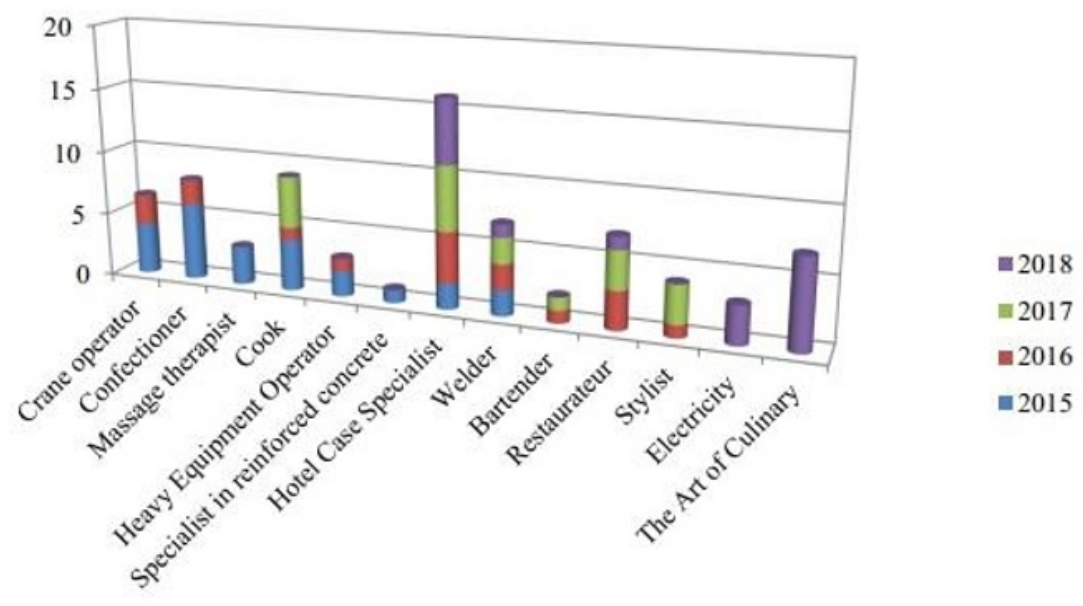

Fig. 1. Distribution of higher education holders by professional directions in 2015-2018. Source: Compiled by the authors based on data from the Employment Agency [11].

The verified data on how many beneficiaries had access to higher education before joining the program have been available to the Agency only since 2015, since only that year it became mandatory to apply for enrolment in the Agency database. For the purposes of this thesis, it is interesting to find out the distribution of the graduates of the accredited / authorized institutions of higher education in Georgia according to the professional directions.

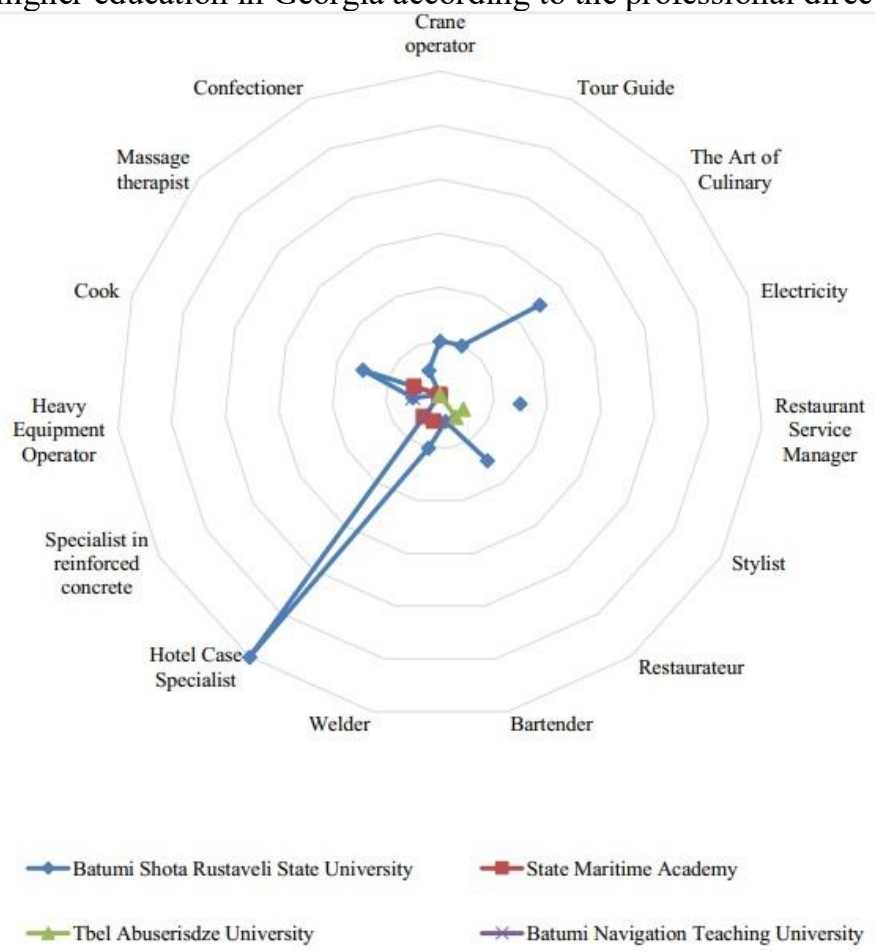

Fig. 2. Source: Compiled by the authors based on data from the Employment Agency [11]. 
Since 2018 in parallel to vocational educational program, the vocational retraining component has started to be implemented that considers to strengthen the qualification of already employed person having one year experience of working in the field or the job seekers offering them short-termed course ( 2 months) compatible with their work to improve their professional skills and obtain the certificate. 1219,2 Gel was spent on it and as a result two persons having HE diploma retrained under various vocational programs were employed at the partner organization of the employment agency.

In total 504 beneficiaries used this sub-program during and 76 out of them had already had Higher education before it.

The given data show that in 2015 to retrain the beneficiaries 9600 GEL was spent and 4 out of 24 beneficiaries were employed; in 2016, 23600 GEL was spent on training of the beneficiaries and 10 out of 15 beneficiaries were employed. In 2017, 25020 GEL was spent and only $50 \%$ of beneficiaries were employed. In 2018, 23749 GEL was spent in the training and 10 beneficiaries out of 17 were employed.

According to the available data, it is obvious that the result of the training and the training expenses were ineffective that is confirmed by the number of employees in relation to the number of trainees.

\section{Conclusions and recommendations}

In Georgia vocational retraining of graduates having had higher education are funded in violation of program budget requirements, and funding increase cannot be considered a step forward if we fail to identify and evaluate the results that must be derived from systematic monitoring of the labor market. Lack of information and availability of few studies do not allow to plan better the vocational training programs while it requires the involvement of various stakeholders such as employers, unemployed, employees, employers' associations and others. Without such discussions it would be complicated to plan and develop efficiently this sector that should play an important role in the development of the economy of the country.

From this, it can be concluded that one of the prior challenges of a Georgia remains to rationalize funding for higher education and vocational training that would positively impact employment and productivity in the country.

\section{References}

1. Abuselidze G and Beridze L 2019 SHS Web of Conferences. EDP Sciences 66 doi:10.1051/shsconf/20196601001

2. Abuselidze G and Mikeladze M 2019 Proceedings of 11th International Conference on Education and New Learning Technologies (EDULEARN 19) doi:10.21125/edulearn.2019.2411

3. Abuselidze G 2019 Proceedings of 5th International Conference on Lifelong Education and Leadership For All (ICLEL 2019) 243

4. Abuselidze G and Mamaladze L 2020 The Impact of Artificial Intelligence on Employment before and during Pandemic: A Comparative Analysis. Journal of Physics: Conference Series

5. Andghuladze N, Bregvadze T and Apazava R 2013 The Impact of Higher Education on Workforce Formation, (Research Report) Tbilisi https://docs.google.com/file/d/0B9RC0lzxY4ZaFFvalc 4ZzRud2s/edit 
6. Bodenhofer H J 1985 Probleme der Bildungsfinanzierung - Zum Stand der Diskussion, Probleme der Bildungsfinanzierung, Publications of the Verein fur Sozialpolitik, Gesellschaftfur Wirtschafts - und Sozialwissenschaften, New Series Berlin http://www.cedefop.europa.eu/files/RR1_Kath.pdf.

7. Bregvadze T 2013 International Institute for Education Policy, Planning and Management Tbilisi https://www.tsu.ge/data/file_db/xarisxis_martvis_dep/ganatlebispolitika-5.pdf

8. Cedefop 2011 Most studies do not record the type of training. Cedefop's literature review found only five studies explicitly examining initial VET's effects on organization performance. Evidence points toa positive effect, but it is limited and weak

9. Courty P, Heinrich C J, Marschke G and Smith J 2011 The performance of performance standards 15

10. Denny $\mathrm{K}$, et al 2003 Education, earnings and skills: a multi-country comparison (London: Institute for Fiscal Studies) 4(8) http://www.ifs.org.uk/ wps/wp0408.pdf

11. 2019 Employment http://adjara.gov.ge/branches/listpage.aspx?pid=110\&gid=3\&ppid=97

Agency

12. European Commission 2019 Higher Education Funding, Eurydice https://eacea.ec.europa.eu/national-policies/eurydice/content/higher-educationfunding-21_bs

13. Government Resolution No400. 2014 Approving Georgia's socio-economic development strategy Georgia 2020 and some related measures Tbilisi http://www.economy.ge/uploads/ecopolitic/2020/saqartvelo_2020.pdf

14. Heckman J J 2008 Economic inquiry 46(3) 289 doi:10.1111/j.1465-7295.2008.00163.x

15. Heckman J J 2011 American Educator 35(1) 31

16. Ministry of Education and Science of Georgia. Unified Strategy for Education and Science for 2017-2021 https://www.mes.gov.ge/content.php?id=7755\&lang=eng.

17. Minister of Education and Sciences of Georgia 2016 Concerning the approval of rules and conditions of program financing of higher educational institutions and approval of those program direction/directions of Bachelor's accredited educational programs of higher educational institutions founded by the state in which students' tuition fees are fully paid by the state, by the Ministry of Education and Sciences of Georgia in 20152016 academic year. Order № 81/n (27.07.2016) http://www.matsne.gov.ge.

18. Nisar M 2015 Higher Education 69289 doi:10.1007/s10734-014-9775-4

19. Schiller D and Liefner I 2006 Higher Education 54543 doi:10.1007/s10734-006-9011$\mathrm{y}$

20. Strehl F, Reisinger S and Kalatschan M 2007 OECD Education Working Papers 6 doi: $10.1787 / 220244801417$

21. Volchik V, Oganesyan A and Olejarz T 2018 Journal of International Studies 11(4) 326 doi:10.14254/2071-8330.2018/11-4/23

22. Woodhull M 2007 Funding higher education: The contribution of economic thinking to debate and policy development (Washington, DC: World Bank Working Paper Series 8, World Bank) 